\title{
Optimalisasi Manajemen Keuangan di MA Darul Ulum Muhammadiyah Galur
}

\author{
Arif Agus Mujahidin', Farid Setiawan², Hanifah Dwi Astiyani' \\ Anisa Listiyani ${ }^{4}$, Latsa Alyautami ${ }^{5}$ \\ 1,2,3,4,5 Program Studi Pendidikan Agama Islam, Fakultas Agama Islam, \\ Universitas Ahmad Dahlan, Yogyakarta, Indonesia \\ Email: ${ }^{1}$ arif1900331031@webmail.uad.ac.id, ${ }^{2}$ farid.setiawan@pai.uad.ac.id, \\ ${ }^{3}$ hanifah1800331029@webmail.uad.ac.id, \\ 4anisalistiyani1911331028@webmail.uad.ac.id, ${ }^{5}$ latsa1900331039@webmail.uad.ac.id
}

\begin{abstract}
This study aims to identify and understand financial management in the MA Darul ulum Muhammadiyah Galur school. The method used in this research is a qualitative approach by means of interviews and observations. The research subject is the School Treasurer. The results of this study indicate the existence of school financial management in fulfilling the educational facilities and infrastructure of MA Darul Ulum Muhammadiyah Galur which aims to determine various kinds of school internal policies that affect the quality and performance of schools. From this research, it shows that MA Darul Ulum Muhammadiyah Galur has managed school finances well which can be seen in the facts that have been found in the field showing that financial management at MA Darul Ulum Muhammadiyah Galur has been effective, efficient and transparent.
\end{abstract}

Keywords: Financial Management, Education.

\begin{abstract}
Abstrak
Penelitian yang dilakukan ini bertujuan guna mengetahui dan memahami suatu manajemen keuangan yang ada disekolah MA Darul ulum Muhammadiyah Galur. Metode yang digunakan dalam penelitian ini dengan pendekatan kualitatif dengan cara wawancara dan obsrvasi. Subjek penelitian adalah Bendahara Sekolah. Hasil penelitian ini menunjukan adanya manajemen keuangan sekolah dalam pemenuhan sarana dan prasarana Pendidikan MA Darul Ulum Muhammadiyah Galur bertujuan menetapkan berbagai macam kebijakan internal sekolah yang berpengaruh pada penigkatan mutu dan kinerja sekolah. Dari penelitian ini menunjukan bahwa MA Darul Ulum Muhammadiyah Galur sudah melakukan pengelolaan keuangan sekolah dengan baik yang terlihat pada fakta yang telah ditemukan di lapangan dengan menunjukan bahwa dalam pengelolaan keuangan di MA Darul Ulum Muhammadiyah Galur sudah efektif, efisien dan transparansi.
\end{abstract}

Kata Kunci: Manajemen Keuangan, Pendidikan 


\section{PENDAHULUAN}

Otonomi wilayah mengacu pada undang-undang nomor 22 dan 25 tahun 1999 akan menentukan system kinerja Pendidikan, baik pada tatanan makro juga mikro. Manajemen Berbasis Sekolah (MBS) dikembangkan guna memberdayakan sekolah pada penetapan banyak sekali kebijakan internal sekolah. Menggunakan adanya MBS maka sekolah mempunyai kewenangan dan keleluasaan menentukan kebijakan sekolah termasuk kebijakan pengelolaan keuangan demi mewujudkan mutu serta kinerja sekolah yang baik.

Pendidikan ialah salah satu kebutuhan paling pada penting saat ini. Biaya atau dana pendidikan artinya komponen yang sangat krusial pada penyelenggaraan pelaksanaan pendidikan. Sehingga dapat disimpulkan bahwa semua aspek yang didalamnya terkait proses pendidikan tak mampu terlaksana tanpa dukungan dana dan biaya. Salah satu unsur dan komponen yang wajib dimiliki suatu sekolah supaya mampu berjalan baik dan lancar berdasarkan segi keuangan yaitu tata kelola keuangan itu sendiri. Pengelolaan keuangan di sekolah memang sangat krusial yang berkaitan dengan pelaksanaan kegiatan dan aktivitas sekolah. Seseorang pengelola keuangan sekolah wajib mempunyai ilmu pengetahuan tentang pengelolaan dan manajemen, khususnya manajemen dalam tata kelola keuangan, karena melaksanakan seluruh aktivitas yang ada disekolah tidak terlepas dari pengolahan biaya dana. Dana yang diperoleh atau diberikan dari pemerintah, juga pihak lain memerlukan tata Kelola dan manajemen yang baik serta tepat sasaran.

Sebanyak apapun dana yang terdapat di sekolah jika tidak ada tata kelola dan tidak menggunakan manajemen yang baik tentu sekolah tadi bisa mengalami kemunduran dan penurunan mutu. Manajemen Finansial menjadi aktifitas yang memperoleh sumber dana, memanfaatkan dana dan mengelola aset secara efisien yang mana memerlukan beberapa tujuan dan target (Harjito, 2005:12). Rohiat (2008:15) menyatakan apabila seorang pemimpin atau kepala sekolah tidak menguasai ilmu manajemen keuangan sekolah dan tanpa pengetahuan manajemen secara umum, maka sistem pendidikan yang dipimpinnya tidak akan berjalan dan terlaksana secara efektif dan efisien, jauh dibawah dari standar mutu, serta keberhasilannya tidak akan memuaskan.

Sekolah mempunyai tugas mengelola sisatem keuangan yang disesuaikan dengan prinsip-prinsip tata kelola keuangan agar uang yang tersedia mampu digunakan secara maksimal. Hal ini dipertegas pada Peraturan Pemerintah Republik Indonesia nomor 39 Tahun 2007 mengenai Pengelolaan Uang Negara/wilayah yang mana pengelolaan keuangan ialah pengelolaan kas serta surat berharga termasuk menanggulangi kekurangan kas serta memanfaatkan kelebihan kas secara optimal. Sekolah menjadi institusi pemerintah yang diawasi sang kepala sekolah yang di Peraturan Pemerintah disebutkan bahwa dalam pengendalian internal serta pengawas fungsional daerah dan Badan Pemeriksa Keuangan di pengendalian fungsional. Tata kelola dana keuangan sekolah dibangun dengan prinsip-prinsip yang termaktub pada Peraturan Pemerintah Republik Indonesia nomor 48 Tahun 2008 ialah mengenai Pendanaan Pendidikan yaitu prinsip transparansi, akuntabel, efektif, serta efisien. Prinsip-prinsip tersebut senada dengan reformasi Kementerian Pendidikan serta Kebudayaan.

Peraturan itu juga mengungkapkan bahwa keempat prinsip yang dipakai di proses tata kelolaan dana sekolah beraswal dari perencanaan, realisasi pemasukan dan pengeluaran dana untuk pendidikan, pengawasan dan pemerikasaan sampai akuntabilitas atau pertanggungjawaban.

Muhammadiyah merupakan organisasi islam yang akbar pada Indonesia. Muhammadiyah ketika masa konvoi Nasional berdiri menjadi sebuah organisasi yang 
berkiprah pada bidang keagamaan, sosial, serta pendidikan. Bidang keagamaan sering mengadakan dakwah islam, bidang sosial memiliki program yaitu salah satunya mendirikan banyak panti asuhan, serta bidang pendidikan mendirikan banyak sekolah mulai dari Taman Kanak-kanak sampai Perguruan Tinggi. Salah satu sekolah menengah yang didirikan Muhammadiyah di daerah Kulon Progo adalah MA Darul Ulum Muhammadiyah Galur.

\section{METODE PENELITIAN}

Metode dalam riset dan penelitian ini menggunakan pendekatan kualitatif dengan cara wawancara dan observasi. Wawancara yang dilakukan dengan mewawancarai salah satu guru Bendahara MA Darul Ulum Muhammadiyah Galur dan pengamatan terhadap sekolah MA Darul Ulum Muhammadiyah Galur. Penelitian ini bermaksud untuk mengetahui bagaimana sistem Manajemen yang ada di sekolah. Pendekatan dilakukan dengan cara induktif dengan memfokuskan terhadap proses manajamen yang ada di sekolahan MA Darul Ulum Muhammadiyah Galur dengan maksud untuk menganalisis proses manajemen sekolah agar sesuai dengan prinsip yaitu transparansi, akuntabel, efektif, dan efisien dan lalu di akhiri dengan kesimpulan.

\section{HASIL PENELITIAN DAN PEMBAHASAN}

\section{Pentingnya Manajemen Keuangan di Sekolah}

Proses pendidikan tidak akan terlepas dengan yang namanya manajemen keuangan. Sehingga perlu adanya pengelolaan keuangan yang efisian dan optimal agar proses pendidikan juga dapat berjalan sesuai dengan apa yang sudah menjadi tujuan bersama. Manajemen keuangan di sekolah ini mempunyai peran besar dan penting dalam tata kelola keuangan yang bertujuan untuk meningkatkan programprogram sekolah, pembangunan sekolah, memperbaiki fasilitas-fasilitas sarana dan prasana sekolah dan bahkan kegiatan yang sifatnya akademik.

Berdasarkan Depdiknas (2000) menegaskan bahwa manajemen keuangan merupakan suatu perbuatan dalam melakukan pengelolaan keuangan yang meliputi atas proses perencanaan, tata pelaksanaan, pertanggungjawaban dan pelaporan. Dengan demikian manajemen keuangan di sekolah dapat dimaknai sebagai aktivitas dalam mengatur keuangan sekolah yang dimulai mulai dari kegiatan perencanaan, pembukuan, pembelanjaan, pengawasan dan pertanggungjawaban keungan sekolah yang nantinya ada bukti pelaporannya.

Dengan adanya aktivitas pengelolaan keuangan ini, maka seluruh kepentingan kebutuhan yang ada kaitannya dengan kegiatan sekolah bisa direncanakan, kemudian diupayakan pendanaannya, dilaporkan secara transparan, dan tentunya bertujuan untuk menopang pelaksanaan program sekolah secara efektif dan efisien. Berdasarkan UU No. 20 Tahun 2003 Pasal 48 manajemen keuangan memiliki 4 prinsip yaitu keadilan, efisiensi, transparansi dan akuntabilitas.

Pertama, Prinsip Keadilan, mempunyai maksud bahwa kebutuhan dana di setiap daerah harus dilihat dari kenyaataan sebenarnya terkait pengelolaan keuangan dimasing- masing sekolah. Kedua, Prinsip Efisiensi, maksudnya disetiap sekolah harus memperhatikan standar anggaran dana yang harus dikeluarkan sehingga dana dapat dikelola secara efektif. Ketiga, Prinsip Transparansi, maksudnya setiapa ada pemasukan atau pengeluaran baik itu berupa barang atau uang yang digunakan untuk membeli sarana dana prasarana sekolah wajib untuk dibukukan dan dilaporkan. Keempat, Prinsip Akuntabilitas, yaitu adanya pertanggungjawaban yang ditinjau dari 
besarnya anggaran yang dikeluarkan. Pihak sekolah memiliki proses pengelolaan terkait penyerapan anggaran sekolah yang nantinya akan digunakan untuk kebutuhan pendidikan disekolah, baik sekolah swasta maupun negeri.

Dana pendidikan disekolah biasanya bersumber atau dikeluarkan oleh pemerintah, yayasan, dan hibah dari donatur. Dana yang berasal dari pemetintah pusat berupa dana BOS (Bantuan Operasional Sekolah) dan subsidi. Setiap daerah memperolah dana BOS yang dialokasikan berdasarkan jumlah siswa sehingga dapat mencukupi sarana dan prasarana pendidikan, perbaikan falisitas dan lingkungan sekolah. Pihak sekolah tidak memungut biaya SPP kepada peserta didik dikarenakan semua dana operasional sekolah bersumber dari dana BOS tersebut. Kemudian untuk dana dari yayasan, karena MA Darul Ulum Muhammadiyah Galur ini berada dibawah naungan muhammadiyah maka sekolah atau madrasah memperoleh dana operasioanal dari persyarikatan muhammadiyah untuk nantinya dikelola sebagaimana mestinya. Untuk dana hibah dari donatur biasanya diperoleh sekolah berupa sumbangan sukarela perorangan atau beberapa kelompok orang yang diberikan sebagai rasa peduli terhadap pembangunan sekolah. Selanjutnya sumber dana dari masyarakat yang biasa kita sebut dengan SPP yang diwaib dibayarkan peserta didik setiap bulannya.

Perlu dipahami juga oleh pihak sekolah bahwa untuk memperoleh dana untuk memenuhi semua kebutuhan sekolah, maka dari sekolah pun harus pandai dan kreatif dalam melihat dan memanfaatkan peluang, baik itu dari pemerintah, komite sekolah maupun dari wali murid. Maka perlu adanya pihak khusus baik itu dari sekolah maupun luar sekolah untuk mengawasi dan mengontrol sumber keuangan yang ada. Berawal dari hal tersebut, diharapkan masyarakat dapat partisipasi aktif dalam mengatur keuangan disekolah, mulai dari perencanaan anggaran, pemenuhan kebutuhan sarana dan prasaran sekolah sampai tahap pengawasannya.

Menurut salah satu Bendahara sekolah di MA Darul Ulum Muhammadiyah Galur, Ari Dhamayanti, S.Pd. menjelaskan bahwa sebagai bendahara sekolah beliau memili peran dan tanggung jawab yang besar karena diamanahi untuk mengelola apapun itu yang ada kaitannya dengan keuangan di sekolah. Seluruh elemen sekolah mulai dari kepala sekolah, staff tata usaha dan bendarahara harus saling bekerja sama dan bersinergi untuk mengelola keuangan disekolah dengan semaksimal mungkin. Proses pengelolaan keuangan yang baik dapat dilakukan oleh pihak-pihak yang baik pula. Peran aktif dari pihak-pihak inilah yang akan menunjang dan memaksimalkan proses didalam mengelola keuangan. Maka dari itu menurut beliau sangat penting dalam mengelola manajemen keuangan, agar dana atau keuangan yang dimiliki sekolah dapat dibelanjakan secara maksimal dan efektif. Apalagi dengan sekolah kecil yang danannya tidak begitu banyak harus dikelola dengan tepat sehingga kebutuhan sekolah bisa terpenuhi. Maka dari itu pengelolaan dana keuangan sekolah harus dikelola dengan penuh tanggung jawab dan teliti agar terhindar dari hal-hal yang tidak diinginkan. Karena suatu lembaga pendidikan yang bagus, pasti didalamya mempunyai sistem pengelolaan keuangan yang bagus pula.

\section{Pengelolaan Keuangan di MA Darul Ulum Muhammadiyah Galur}

Keuangan merupakan sebuah hal terpenting penunjang keberlangsungan atau efektifitas dalam lembaga pendidikan. Pengelolaan yang baik akan menunjang sekolah atau madrasah tertib dalam administrasi, pengelolaan keuangan yang tepat juga merupakan salah satu bentuk implementasi dari menejemen dalam pendidikan. Pengelolaan keuangan madrasah menjadi bagian dari pembiayaan pendidikan yang dalam praktiknya menuntut pihak pengelola keuangan madrasah untuk merencanankan, melaksanakan, dan mempertanggung jawabkan keuangan secara 
transparan.

1. Perencanaan

Perencanaan merupakan proses awal dalam pengelolaan anggaran. Perencanaan keuangan termasuk dalam menejemen keuangan yang terencana dan bersifat fundamental. Perencanaan anggaran di MA Darul Ulum Muhammadiyah Galur biasanya dilakukan dengan cara bendahara madrasah menanyakan kepada waka kurikulum, sarana prasana untuk mengetahui apa saja yang nantinya diperlukan untuk dimasukan kedalam rancangan anggaran dana. Setelah itu kemudian perencanaan disusun secara sistematis meliputi seluruh anggaran kegiatan madrasah dan dirapatkan dalam rapat komite bersama dengan wali murid untuk memutuskan apa yang direncankan. Ibu Ari Dhamayanti S.Pd selaku bendahara di MA Darul Ulum Muhammadiyah Galur mengatakan bahwa "Pengelolaan dilakukan setiap awal tahun anggaran, biasanya bendahara akan menanyakan ke waka sarpras dan waka kurikulum untuk kegiatan ditahun tersebut sehingga bendahara bisa merencanakan apa saja pengeluaran kemudian pelaksanaan dilakukan oleh bendahara dan penanggungjawab tiap kegiatan dan laporan dilakukan diakhir tahun."

\section{Pelaksanaan}

Pelaksanaan keuangan dalam pendidikan berbasis madrasah biasanya dilakukan melalui dua aspek, yang pertama yaitu perlunya pembukuan penerimaan sumber-sumber dana sesuai dengan prosedur pengelolaan yang telah ditetapkan dan disepakati. Hal ini dilakukan agar pelaksanaannya tidak rancu. Kedua yaitu pengeluaran, pengeluaran madrasah meliputi pembelian atau output guna berjalannya kegiatan dimadrasah. Diantaranya yaitu, tenaga administrasi, pengelola madrasah, guru, perlengkapan, bahan- bahan dalam kegiatan belajar mengajar, serta sarana dan prasarana. Dalam konsep menejemen keuangan madrasah pengeluaran juga harus dibukukan sesuai dengan peraturan yang telah ditetapkan agar tersusun secara rapi dan mudah untuk dipahami.

\section{Transparansi dan Pertanggungjawaban}

Dalam pengelolaan keuangan transparansi sangat diperlukan karena uang merupakan hal yang sensistif dan penting. Transparansi sendiri berasal dari kata transparan yang artinya terbuka. Dalam hal pengelolaan keuangan transparan berarati adanya keterbukaan dalam mengelola keuangan tidak ada yang ditutup-tutupi. Keterbukaan yang dimaksud meliputi sumber keungan berasal dari mana, rincian penggunaan, serta pertanggungjawaban yang jelas agar pihak-pihak yang bersangkutan mengetahuinya. Transparansi keuangan dilakukan agar tercipta rasa percaya antara orang tua siswa, masyarakat, warga sekolah serta pemerintah terhadap pihak pengelola keuangan termasuk sekolah atau madrasah. MA Darul Ulum Muhammadiyah Galur telah melakukan transparansi terkait pengelolaan keuangan dengan menyelenggarakan rapat komite dan biasanya dilakukan dalam waktu setahun sekali. Dalam rapat komite tersebut biasanya bendahara madrasah menyampaikan jumlah dana masuk beserta sumbernya kemudian dialokasikan untuk apa saja dan sisa dana setelah digunakan. Selain itu bendahara madrasah juga mempertanggungjawabkan sesuai dengan perencanaan yang sebelumnya telah ditetapkan.

\section{PENUTUP}

Menejemen keuangan sekolah atau madrasah merupakan upaya pengaturan sebuah keuangan sekolah dengan meliputi sebuah perencanaan, pembukuan, pembelanjaan, pengawasan dan pertanggungjawaban keungan sekolah yang nantinya ada bukti pelaporannya. Adanya menejemen keuangan ini agar antara guru, peserta 
didik, orang tua atau wali siswa bahkan pemerintah percaya terhadap pengelola keuangan sekolah atau madrasah. Selain itu adanya menejemen keuangan yang terstruktur akan menghasilkan output yang baik bagi pengelolaan keuangan disekolah. Ada beberapa prinsip dalam pengelolaan keuangan diantaranya yaitu prinsip keadilan, efisiensi, transparansi dan akuntabilitas. Apabila prinsip-prinsip ini berjalan dengan baik maka sistem menejemen pengelolaan keuangan sekolah sudah sangat baik. Di MA Darul Ulum Muhammadiyah Galur bersumber atau dikeluarkan oleh pemerintah, yayasan, dan hibah dari donatur. Dana yang berasal dari pemetintah pusat berupa dana BOS (Bantuan Operasional Sekolah). Untuk dana dari yayasan, MA Darul Ulum Muhammadiyah Galur memperoleh dana operasioanal dari persyarikatan muhammadiyah untuk nantinya dikelola sebagaimana mestinya. Kemudian dana hibah dari donatur biasanya diperoleh sekolah berupa sumbangan sukarela perorangan atau beberapa kelompok orang yang diberikan sebagai rasa peduli terhadap pembangunan sekolah. Dana-dana yang diperoleh dialokasikan sesuai dengan kebutuhan sekolah atau madrasah.

\section{DAFTAR RUJUKAN}

Adillah, G. (2016). Manajemen Keuangan Sekolah. Jurnal Manajer Pendidikan, 10(4), 343-346.

Anam, K. (2019). Manajemen Keuangan Madrasah yang Bersumber dari Masyarakat. Jurnal At-Turats, 13(1), 56-75.

Andiawati, Etty. (2017). Pengelolaan Keuangan Lembaga Pendidikan/Sekolah. Prosiding Seminar Pendidikan Ekonomi dan Bisnis, 3(1), 1-6.

Asmani, Jamal Ma'mur. (2012). Tips Sakti Membangun Organisasi Sekolah. Yogyakarta: Diva Press.

Fajar, N., \& Arfan, M. (2017). Analisis Penyerapan Anggaran Pada Satuan Kerja Perangkat Aceh. Jurnal Telaah dan Riset Akuntansi, 10(2), 95-102.

Fattah, Nanang. (2016). Landasan Manajemen Pendidikan. Bandung: PT Remaja

Harjito, Agus dan Martono. (2007). Manajemen Keuangan. Jogyakarta: Ekonisia. UI.

Mubin, N. (2018). Integritas dan Akuntabilitas dalam Pengelolaan Keuangan Sekolah/Madrasah. Jurnal At-Taqwa, 14(2), 80-92.

Muhaimin, dkk. (2009). Manajemen Pendidikan. Jakarta: Prenada Media.

Pusvitasari, Rita dan Mukhamad Sukur. (2020). Manajemen Keuangan Sekolah Dalam Pemenuhan Sarana Prasarana Pendidikan (Studi kasus di SD Muhammadiyah 1 Krian, Sidoarjo). Al-Tanzim : Jurnal Manajemen Pendidikan Islam, 4(1), 98.

Qomar, Mujamil. (2007). Manajemen Pendidikan Islam. Jakarta: Erlangga.

Rohiat. (2008). Manajemen Sekolah. Bandung: Refika Aditama.Rosdakarya.

Sulistyorini. (2014). Esensi Manajemen Pendidikan Islam. Yogyakarta: Teras.

Usman, Jaamiludin. (2016). Urgensi Manajemen Pembiayaan Dalam Peningkatan Mutu Pendidikan Madrasah. Tadris: Jurnal Pendidikan Islam, 11(2), 219-246. 